\title{
Electroless deposition of nickel boron coatings using morpholine borane as a reducing agent
}

Zita Sukackienè $\dot{e}^{\star}$

Kornelija Antanavičiūtè,

Jūratè Vaičiūnienè,

Loreta Tamašauskaitè-Tamašiūnaitè,

Arnas Naujokaitis,

Eugenijus Norkus

Department of Catalysis,

Center for Physical Sciences and Technology,

3 Sauletekio Avenue,

10257 Vilnius, Lithuania
Nickel boron $(\mathrm{NiB})$ coatings were deposited onto copper using a nickelglycine (Ni-Gly) plating solution and morpholine borane (MB) as a reducing agent. It has been determined that using $\mathrm{MB}$ as a reducing agent in the Ni-Gly plating solution produces $\mathrm{NiB}$ coatings, which exhibit typical cauliflower-like textures. The deposition rate of the $\mathrm{NiB}$ coatings and their composition depend on the concentrations of the reducing agent $(\mathrm{MB})$ and the ligand (Gly), in addition to the $\mathrm{pH}$ and temperature of the plating solution. The highest deposition rate $\left(3.42 \mathrm{mg} \mathrm{cm}^{-2} \mathrm{~h}^{-1}\right)$ of the $\mathrm{NiB}$ coating was obtained when the plating bath was operated at $\mathrm{pH} 5$ and $60^{\circ} \mathrm{C}$ temperature. Using this method, $\mathrm{NiB}$ coatings containing 10-20 at.\% of boron can be obtained.

Keywords: electroless deposition, nickel, boron, morpholine borane, glycine

\section{INTRODUCTION}

Nickel and its alloy coatings obtained using the electroless metal deposition technique are widely used in many different areas of industry such as electronics, automotive, aerospace, medical, petrochemical and military applications. Such a wide field of application can be explained by a well-known combination of $\mathrm{Ni}$ and the properties of its alloys, such as high corrosion resistance, excellent wear resistance, uniformity of coating and magnetic properties [1-8]. Nickel-phosphorous alloys, which are obtained using sodium phosphinate as the reducing agent, are the most widely used and studied [9-12],

\footnotetext{
* Corresponding author. Email: zita.sukackiene@ftmc.lt, zitaja@gmail.com
}

as they exhibit a very high corrosion resistance in very aggressive acidic media [13]. Ni coatings, containing boron, have also been widely investigated. Sodium and potassium borohydride are the most popular reducing agents used in the literature, but electroless plating with $\mathrm{NaBH}_{4}$ solutions requires elevated temperatures $\left(90-95^{\circ} \mathrm{C}\right)$ and a strong alkaline medium ( $\mathrm{pH} 12-14)$ to achieve high deposition rates [14]. $\mathrm{NiB}$ alloys produced using $\mathrm{NaBH}_{4}$ or amine borane compounds as the reducing agents are commonly reported in the literature; moreover, such $\mathrm{NiB}$ alloys are often described as high-performance coatings. The process of $\mathrm{NiB}$ coating deposition is simple and the chemicals used are relatively cheap, which makes $\mathrm{NiB}$ coatings more popular than other Ni alloy coatings used in industry. It is well known that boron containing compounds are 
stronger reducing agents as compared to phosphinates [15, 16]. Ni coatings containing boron exhibit higher hardness and better corrosion resistance as compared to those of $\mathrm{Ni}$ films with $\mathrm{P}$ [17-22]. The hardness of the $\mathrm{NiB}$ coatings increases with the amount of boron incorporated, while the corrosion resistance seems to be favourably influenced by higher boron concentrations [23]. As mentioned, electroless $\mathrm{NiB}$ coatings can be deposited using reducing agents such as borohydride [17, 24, 25] and amine boranes [26-30]. Amine boranes are effective reducing agents because they can be used in a wider range of $\mathrm{pH}$, compared to the borohydrides. Ni plating baths employing amine boranes can operate in both acid and alkaline conditions. Dimethylamine borane $(\mathrm{DMAB})$ is one of the most popular reducing agents among other amine boranes. $\mathrm{NiB}$ coatings fabricated via electroless deposition find extensive applications in different industrial fields due to simplicity of electroless deposition processes. DMAB, giving 6 electrons, is a stronger reducing agent in comparison to phosphinate, which gives only 2 electrons. The use of a stronger reducing agent, e.g. $\mathrm{DMAB}$, for electroless metal deposition yields a selfactivated (Pd-free) deposition [31, 32]. This process does not require the use of $\mathrm{Pd}$ nuclei for activation of the substrate due to the application of a stronger reducing agent [33]. Self-activated processes have been shown for cobalt deposition [31, 34-37]. As a result of these self-activated processes, highly selective Cobased metal films were formed directly on $\mathrm{Cu}$ lines when a DMAB was used as a reducing agent [37].

In the literature, some authors mention another boron-containing reducing agent - morpholine borane $(\mathrm{MB})$, which has not been widely used in the electroless metal deposition to date. Previously, it was found that using $\mathrm{MB}$ as a reducing agent produced high-quality cobalt-boron coatings at a relatively low temperature of $30^{\circ} \mathrm{C}$ [16]. The suitability of $\mathrm{MB}$ to act as a reducing agent for the electroless deposition of metals is mentioned in some other works [16, 38-42]. However, there are practically no detailed data concerning this process or the properties of the coatings obtained. Compared to DMAB, MB is less volatile and toxic [43]. Therefore, the aim of this work was to investigate, in detail, electroless $\mathrm{Ni}$ deposition using $\mathrm{MB}$ as a reducing agent and plating solutions containing the additional ligand - glycine. We propose a new Ni plating bath using $\mathrm{MB}$ as a reducing agent, which has not yet been thoroughly investigated. The main advantage of using $\mathrm{MB}$ as a reducing agent is the possibility to regulate and predict the composition (namely, the content of $\mathrm{Ni}$ and $\mathrm{B}$ ) of the $\mathrm{NiB}$ coatings produced.

\section{EXPERIMENT}

The $\mathrm{NiB}$ coatings were deposited on a $1 \times 1 \mathrm{~cm} \mathrm{Cu}$ sheet (model: C10200 pure copper plate, $99.90 \% \mathrm{pu}$ rity, $0.4 \mathrm{~mm}$ thick). Prior to the electroless deposition of $\mathrm{NiB}$ coatings, the surface of the $\mathrm{Cu}$ sheet was pretreated with $\mathrm{SiC}$ emery paper (grade 2500) and $\mathrm{MgO}$ powder, then etched in $10 \% \mathrm{H}_{2} \mathrm{SO}_{4}$ and rinsed with deionized water. After this degreasing procedure, $\mathrm{Cu}$ sheets were activated with $\mathrm{Pd}^{2+}$ ions by their immersion in a $0.5 \mathrm{~g} \mathrm{~L}^{-1} \mathrm{PdCl}_{2}$ solution for $5 \mathrm{~s}$, rinsed with deionized water and placed into an electroless $\mathrm{Ni}$ plating solution. The geometric area of the $\mathrm{Cu}$ sheet was $2 \mathrm{~cm}^{2}$. The main composition of the electroless plating solution was the following $\left(\mathrm{mol} \mathrm{L}^{-1}\right)$ : $\mathrm{NiSO}_{4}-0.05, \mathrm{C}_{4} \mathrm{H}_{8} \mathrm{ONH} \cdot \mathrm{BH}_{3}(\mathrm{MB})-0.02-0.30$, $\mathrm{NH}_{2} \mathrm{CH}_{2} \mathrm{COOH}$ (glycine) $-0.40, \mathrm{CH}_{3} \mathrm{COONa}$ (sodium acetate) -0.04 . The deposition of coatings was performed from a freshly prepared solution at temperatures of 30 up to $60^{\circ} \mathrm{C}$. The plating solution $\mathrm{pH}$ was in a range of 5-7. All chemicals used were of analytical purity grade. The thickness of the deposited films was determined from gravimetric data. The average deposition rate in $\mathrm{mg} \mathrm{cm}^{-2} \mathrm{~h}^{-1}$ was calculated from at least three measurements. The surface morphology of the samples was characterized using a SEM/FIB Workstation Helios Nanolab 650 (FEI) arranged with an energy dispersive X-ray (EDX) spectrometer INCA Energy 350X-Max 20. TEM (XTEM) images of the cross-sections of the $\mathrm{NiB}$ coatings were done using an FEI TECNAI F20 field emission transmission electron microscope operated at $200 \mathrm{kV}$. The XTEM specimens were prepared by the FIB lift-out technique in the Helios NanoLab 650 dual beam microscope. Cross-sections were performed using a focused ion beam (FIB) with $30 \mathrm{keV}$ energy Ga ions. Platinum was introduced on the top of the surface during sample cross sectioning.

The composition of the obtained $\mathrm{NiB}$ coatings was estimated using inductively coupled plasma optical emission spectroscopy (ICP-OES). ICP optical emission spectra were recorded using an ICP optical emission spectrometer Optima 7000DV (Perkin Elmer). The data on coating composition 
and deposition rates presented in this paper represent the average of at least three measurements. The variability of these measurements was found to be well within $\pm 2 \%$ in all cases.

\section{RESULTS AND DISCUSSION}

Electroless $\mathrm{Ni}$ plating solutions containing Gly, $\mathrm{CH}_{3} \mathrm{COONa}$ and $\mathrm{MB}$ as a reducing agent are stable and may be used for deposition of the $\mathrm{NiB}$ coatings. Electroless deposition of the $\mathrm{NiB}$ coatings, using $\mathrm{MB}$ as a reducing agent, is a rather simple process; moreover, it can be viewed as the sum of two chemical reactions occurring simultaneously: the oxidation of MB on the catalytic surface (1) and the reduction of $\mathrm{Ni}^{2+}$ and $\mathrm{B}^{3+}$ ions $(2,3)$ :

$$
\begin{aligned}
& \mathrm{C}_{4} \mathrm{H}_{8} \mathrm{ONH} \cdot \mathrm{BH}_{3}(\mathrm{aq})+3 \mathrm{HOH}(\mathrm{aq})+\mathrm{OH}^{-}(\mathrm{aq}) \rightarrow \\
& \mathrm{C}_{4} \mathrm{H}_{8} \mathrm{OH}_{2} \mathrm{~N}^{+}(\mathrm{aq})+\mathrm{B}(\mathrm{OH})_{4}^{-}(\mathrm{aq})+ \\
& +5 \mathrm{H}^{+}(\mathrm{aq})+6 \mathrm{e}^{-} \\
& \mathrm{Ni}^{2+}+2 \mathrm{e}^{-} \rightarrow \mathrm{Ni}^{0} \\
& \mathrm{~B}^{3+}+3 \mathrm{e}^{-} \rightarrow \mathrm{B}^{0}
\end{aligned}
$$

The electrons removed during the oxidation of $\mathrm{MB}$ are used in the reactions for reduction of $\mathrm{Ni}^{2+}$ and $\mathrm{B}$ ions. The overall reaction of electroless deposition of $\mathrm{NiB}$ coatings may be described as follows (Eqs. 4, 5):

$$
\begin{aligned}
& \mathrm{C}_{4} \mathrm{H}_{8} \mathrm{ONH} \cdot \mathrm{BH}_{3}(\mathrm{aq})+4 \mathrm{H}_{2} \mathrm{O}(\mathrm{aq})+1.5 \mathrm{Ni}^{2+}(\mathrm{aq}) \rightarrow \\
& 1.5 \mathrm{Ni}^{0}(\mathrm{~s})+\mathrm{C}_{4} \mathrm{H}_{8} \mathrm{OH}_{2} \mathrm{~N}^{+}(\mathrm{aq})+\mathrm{B}(\mathrm{OH})_{4}^{-}(\mathrm{aq})+ \\
& +1.5 \mathrm{H}_{2}(\mathrm{~g})+3 \mathrm{H}^{+}(\mathrm{aq}) \text {, } \\
& \mathrm{C}_{4} \mathrm{H}_{8} \mathrm{ONH} \cdot \mathrm{BH}_{3}(\mathrm{aq})+\mathrm{H}^{+}(\mathrm{aq}) \rightarrow \\
& \mathrm{B}^{0}(\mathrm{~s})+\mathrm{C}_{4} \mathrm{H}_{8} \mathrm{OH}_{2} \mathrm{~N}^{+}(\mathrm{aq})+1.5 \mathrm{H}_{2}(\mathrm{~g}) \text {. }
\end{aligned}
$$

At the same time, some quantity of MB may also be consumed in the following unproductive decomposition reaction (6):

$$
\begin{aligned}
& \mathrm{C}_{4} \mathrm{H}_{8} \mathrm{ONH} \cdot \mathrm{BH}_{3}(\mathrm{aq})+4 \mathrm{H}_{2} \mathrm{O}(\mathrm{aq}) \rightarrow \\
& \mathrm{C}_{4} \mathrm{H}_{8} \mathrm{OH}_{2} \mathrm{~N}^{+}(\mathrm{aq})+\mathrm{B}(\mathrm{OH})_{4}^{-}(\mathrm{aq})+3 \mathrm{H}_{2}(\mathrm{~g}) .
\end{aligned}
$$

$\mathrm{NiB}$ alloy coatings were deposited on the $\mathrm{Cu}$ surface using the plating baths operated at different $\mathrm{pH}$ values between 5-8 and different temperatures in the range $30-60^{\circ} \mathrm{C}$. Figure 1 presents the dependence of the deposition rate $\left(\mathrm{mg} \mathrm{cm}^{-2} \mathrm{~h}^{-1}\right)$ of the $\mathrm{NiB}$ coatings and their composition on the plating bath $\mathrm{pH}$. The bath was operated at $30^{\circ} \mathrm{C}$ temperature and the concentration of $\mathrm{MB}$ was $0.02 \mathrm{~mol} \mathrm{~L}^{-1}$. As seen from the data in Fig. $1 \mathrm{a}$, the deposition rate decreases with an increase in solution $\mathrm{pH}$ over the whole investigated $\mathrm{pH}$ range. A significant decrease of the deposition rate is visible in a range of $\mathrm{pH} 7-8$. The deposition rate decreases almost

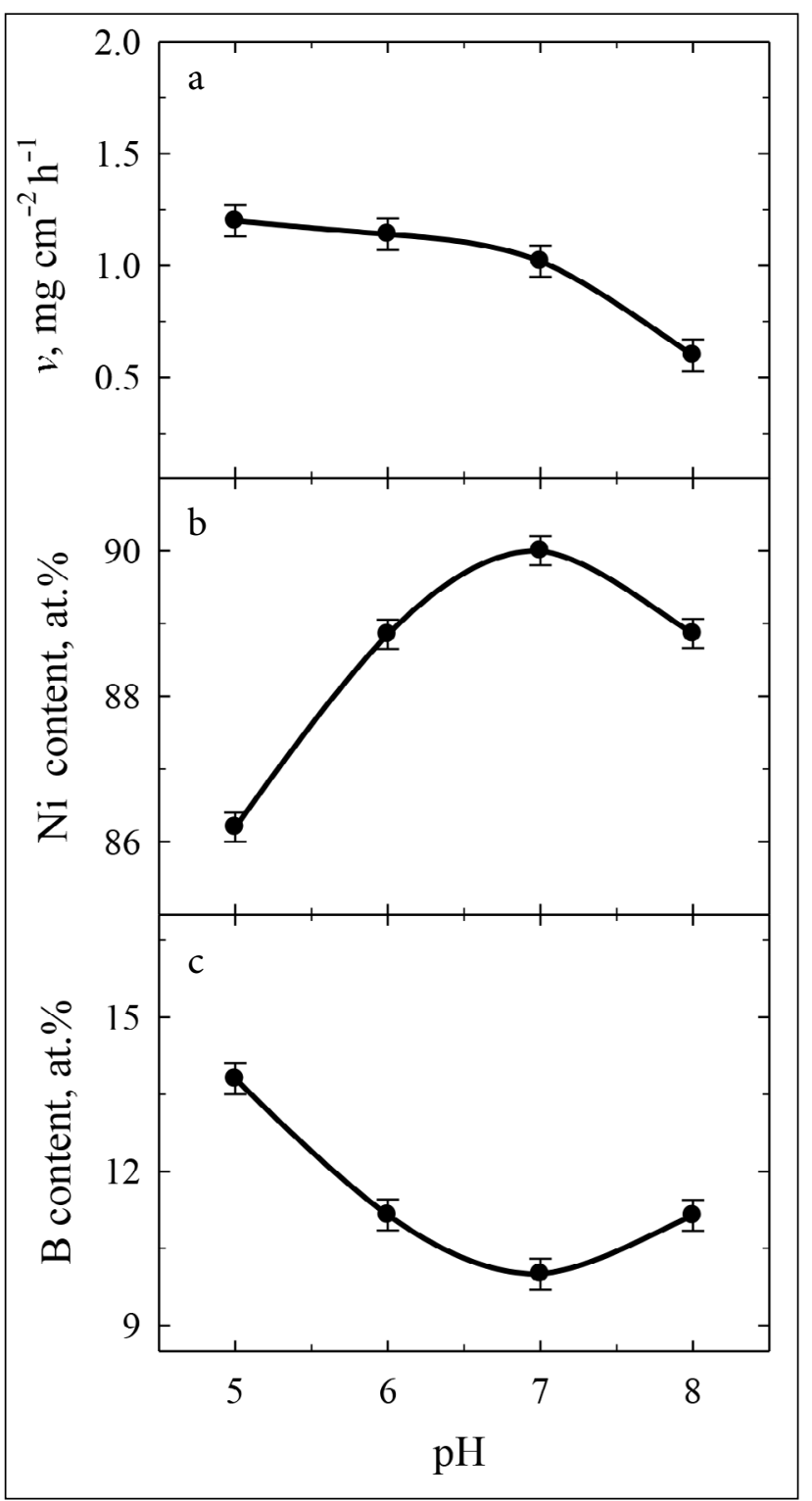

Fig. 1. Influence of plating bath $\mathrm{pH}$ on the deposition rate of NiB coatings and their composition. The solution composition $\left(\mathrm{mol} \mathrm{L}^{-1}\right)$ : $\mathrm{NiSO}_{4}-0.05, \mathrm{MB}-0.02, \mathrm{CH}_{3} \mathrm{COONa}-0.04, \mathrm{Gly}-0.40,30^{\circ} \mathrm{C}$ 
twice. The highest $\mathrm{NiB}$ coating deposition rate of $1.20 \mathrm{mg} \mathrm{cm}^{-2} \mathrm{~h}^{-1}$ was obtained in the plating bath operated at $\mathrm{pH} 5$. In addition, the highest boron content of 14.2 at.\% was also achieved for the NiB coatings produced at $\mathrm{pH} 5$ (Fig. 11 c). With an increase in the plating solution $\mathrm{pH}$ from 5 to 7 , the boron content in the $\mathrm{NiB}$ films was found to diminish, but a further increase in solution $\mathrm{pH}$ leads to a slight increase in the boron content (Fig. 11 c). Furthermore, the amount of $\mathrm{Ni}$ in the $\mathrm{NiB}$ coatings increases with the plating bath $\mathrm{pH}$ up to $\mathrm{pH} 7$, followed by a decrease in the Ni content as the $\mathrm{pH}$ was increased further (Fig. $1 \mathrm{~b}$ ). It has been determined that the $\mathrm{NiB}$ coating with the highest $\mathrm{Ni}$ content of 90 at.\% and the lowest boron content of 10 at.\% were deposited from the plating bath operated at $\mathrm{pH} 7$. Figure 2 shows the surface morphology of as-prepared $\mathrm{NiB}$ coatings deposited from the plating bath operated
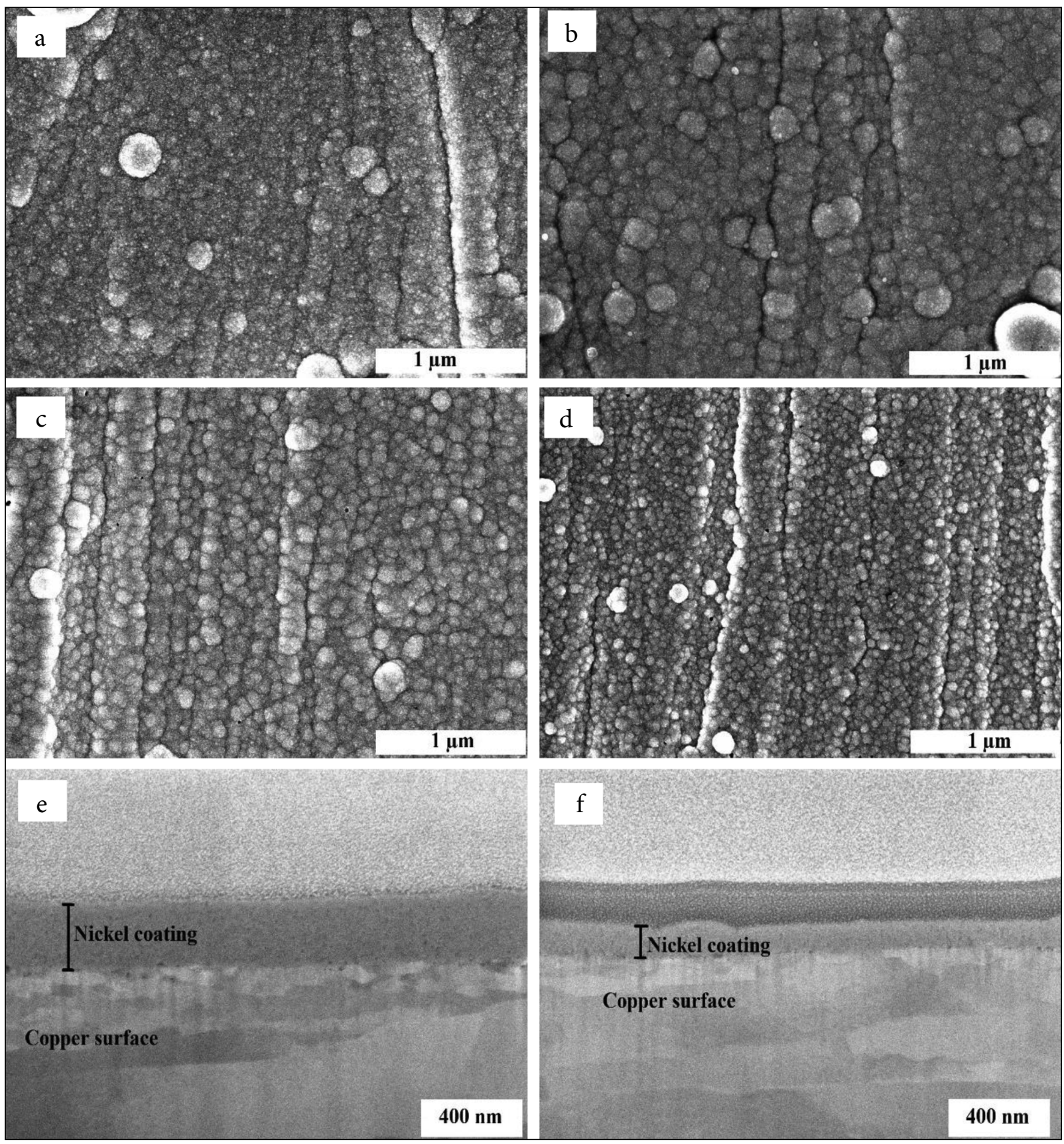

Fig. 2. SEM images of as-prepared NiB coatings deposited on the Cu surface from the solution containing ( $\left.\mathrm{mol} \mathrm{L}^{-1}\right)$ : $\mathrm{NiSO}_{4}-0.05, \mathrm{MB}-0.02$, $\mathrm{CH}_{3} \mathrm{COONa}-0.04$, Gly $-0.40, \mathrm{pH}: 5$ (a), 6 (b), 7 (c) and 8 (d), $30^{\circ} \mathrm{C}$. Part of Fig. e and f represents the TEM images of the cross-section of the NiB coatings deposited on the Cu surface from the same solution at $\mathrm{pH} 5$ and 7 , respectively 
at different pH values: 5 (a), 6 (b), 7 (c) and 8 (d). As evident from the data in Fig. 2, the surface morphology of all the coatings presents a typical cauliflower-like texture [44-48]; however, the surface morphology of the $\mathrm{NiB}$ coatings depends on the plating bath $\mathrm{pH}$. It is clearly seen that all the coatings are nodulous, and with an increase in plating bath $\mathrm{pH}$, the size of the surface features is significantly modified. Notably, at $\mathrm{pH} 5$, the $\mathrm{NiB}$ coatings consisted of larger nodules ranging in size from approximately 130 to $340 \mathrm{~nm}$ and had the highest boron content (Fig. 2a), while coatings composed of smaller nodules of 50-160 $\mathrm{nm}$ in size were obtained from the solution at $\mathrm{pH} 8$ (Fig. 2d).

TEM images of the cross-sections of the $\mathrm{NiB}$ coatings deposited from the plating bath operated at $\mathrm{pH} 5$ and 7 are shown in Fig. 2e and f. It is evident that the $\mathrm{NiB}$ coatings deposited on the $\mathrm{Cu}$ surface are dense and continuous (Fig. 2e, f).

In spite of the fact that hydroxide ions influence oxidation of the reducing agent (MB), an increase in plating bath $\mathrm{pH}$ does not increase the plating rate of the $\mathrm{NiB}$ coating. It is thought that more stable $\mathrm{Ni}^{2+}$ complexes with Gly are formed in more alkaline media. As a result, the reduction of $\mathrm{Ni}^{2+}$ ions to Ni metal occurs via a more complicated pathway. The increase in plating bath $\mathrm{pH}$ from 5 to 8 results in a decrease in the plating rate of the $\mathrm{NiB}$ coatings. Moreover, a higher $\mathrm{B}$ content is incorporated in the coating as soon as the deposition rate begins to decrease (Fig. 1). A similar phenomenon was observed for the deposition of the NiP films from the Ni-Gly plating bath using sodium phosphinate as a reducing agent 49 . It should be noted that below $\mathrm{pH} 4$, the Ni-Gly plating solutions are not stable, and the reduction of $\mathrm{Ni}^{2+}$ ions with $\mathrm{MB}$ occurs in the solution bulk.

The influence of the deposition rate of $\mathrm{NiB}$ coatings and their composition on the concentration of a reducing agent, e.g. $\mathrm{MB}$, in the plating bath operated at $\mathrm{pH} 7$ and at $30^{\circ} \mathrm{C}$ temperature is shown in Fig. 3. The results obtained have shown that the deposition rate of the $\mathrm{NiB}$ coatings remains practically unchanged with an increase in the concentration of MB from 0.02 to $0.10 \mathrm{~mol} \mathrm{~L}^{-1}$ (Fig. 3a). With a further increase in the $\mathrm{MB}$ concentration from 0.10 to $0.30 \mathrm{~mol} \mathrm{~L}^{-1}$, the deposition rate of the $\mathrm{NiB}$ coatings significantly decreases (Fig. 3a). The highest deposition rate of $1.02 \mathrm{mg} \mathrm{cm}^{-2} \mathrm{~h}^{-1}$ is obtained when the concen-

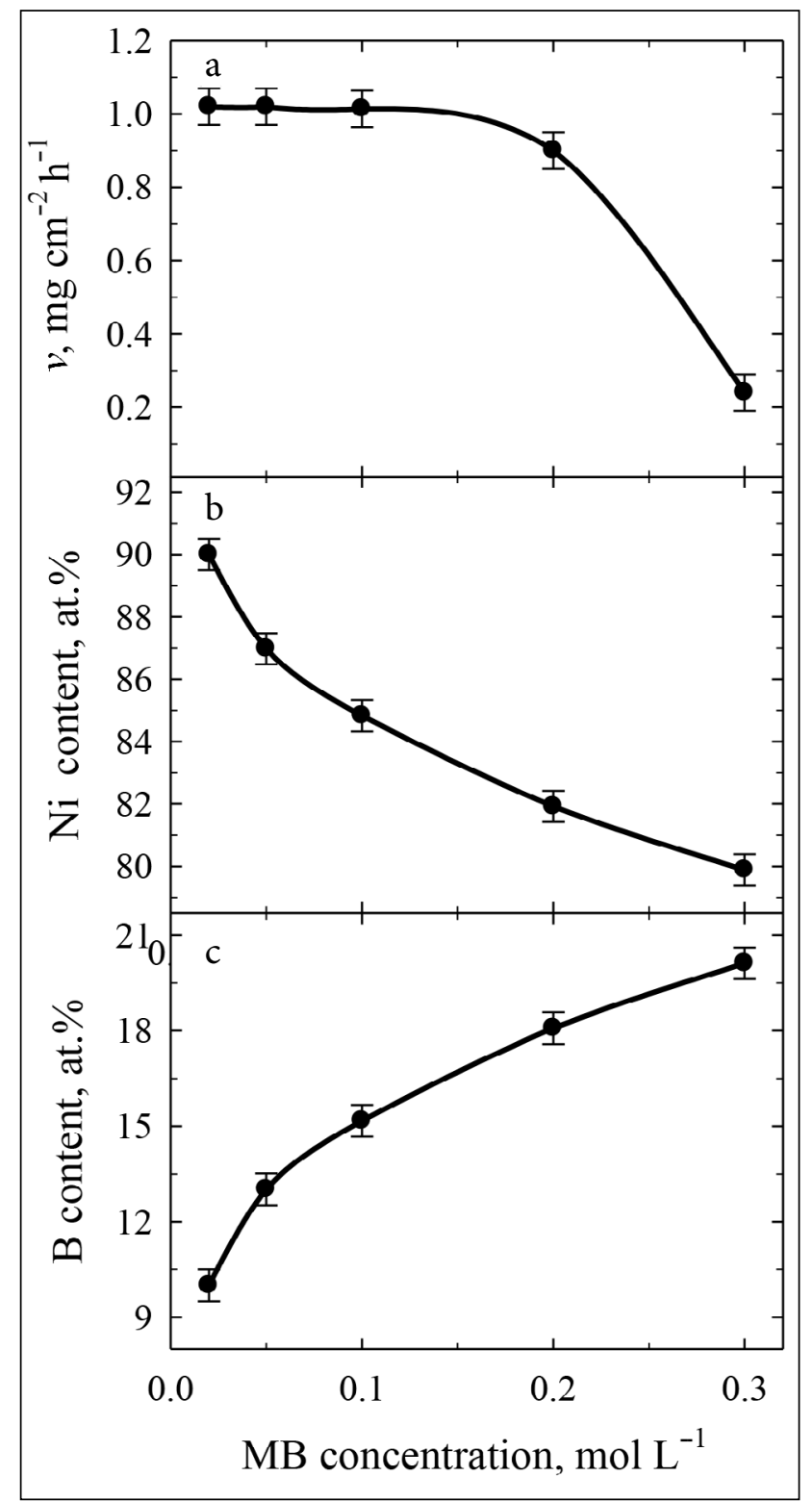

Fig. 3. Influence of the $M B$ concentration on the deposition rate of the NiB coatings ( $a$ ) and their composition (b, c). The solution composition $\left(\mathrm{mol} \mathrm{L}^{-1}\right): \mathrm{NiSO}_{4}-0.05, \mathrm{CH}_{3} \mathrm{COONa}-0.04, \mathrm{Gly}-0.40, \mathrm{pH} 7,30^{\circ} \mathrm{C}$

tration of $\mathrm{MB}$ in the plating solution is in a range of $0.02-0.10 \mathrm{~mol} \mathrm{~L}^{-1}$. A general trend is observed: on the one hand, the Ni content in the coatings decreases from 90 to 80 at.\% (Fig. 3 b), on the other hand, the amount of boron simultaneously increases from 10 to 20 at.\% (Fig. $3 \mathrm{c}$ ), in the cases when the $\mathrm{MB}$ concentration in the plating solution is elevated from 0.02 to $0.30 \mathrm{~mol} \mathrm{~L}^{-1}$.

The SEM images of the NiB coatings deposited on the $\mathrm{Cu}$ surface from the Ni-Gly plating baths, containing different concentrations of the reducing agent, $\mathrm{MB}$, and operated at $\mathrm{pH} 7$ and at $30^{\circ} \mathrm{C}$ temperature, are given in Fig. $4(\mathrm{a}-\mathrm{c})$. A cross-section 

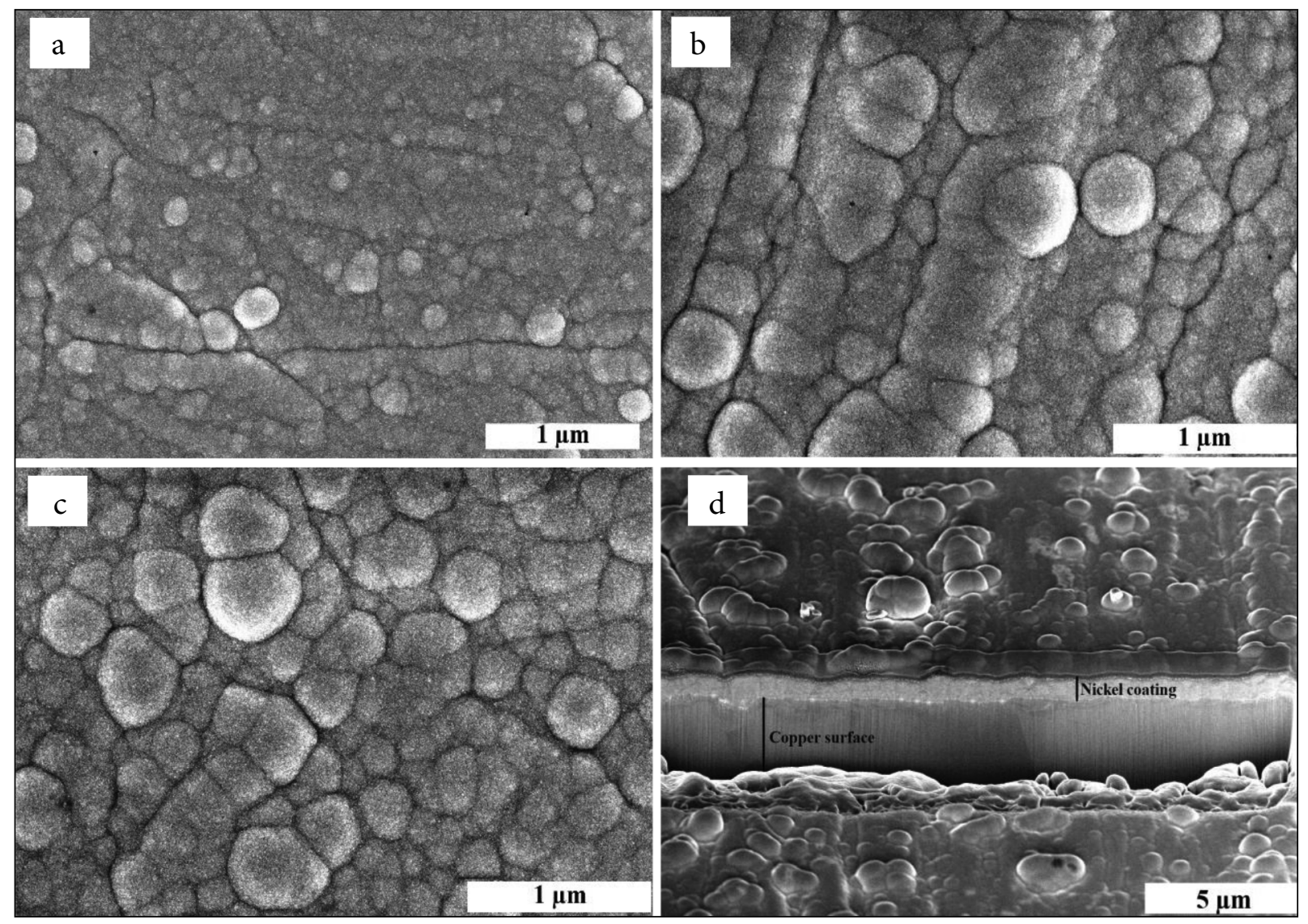

Fig. 4. SEM images (a-c) of as-prepared NiB coatings deposited on the Cu surface from the solution containing ( $\left.\mathrm{mol} \mathrm{L}^{-1}\right)$ : $\mathrm{NiSO}_{4}-0.05$, $\mathrm{CH}_{3} \mathrm{COONa}-0.04, \mathrm{Gly}-0.40, \mathrm{MB}-0.05$ (a), 0.1 (b) and 0.2 (c), pH 7, $30^{\circ} \mathrm{C}$. Part of Fig. $d$ represents the cross-section TEM image of the NiB coating deposited on the Cu surface in the same plating solution containing $0.05 \mathrm{~mol} \mathrm{~L}^{-1}$ of MB

TEM image of the NiB coating, which was deposited on the $\mathrm{Cu}$ surface when the MB concentration in the plating bath was $0.05 \mathrm{~mol} \mathrm{~L}^{-1}$, is shown in Fig. 4d. The deposited $\mathrm{NiB}$ coatings have also a cauliflower-like texture as shown in Fig. $4(a-c)$. It can be noted that an increase in the $\mathrm{MB}$ concentration from 0.02 (Fig. 20) to 0.20 (Fig. $4 a-c$ ) mol $\mathrm{L}^{-1}$ in the plating solution caused a formation of more pronounced nodulus in the coatings obtained. A lower concentration of $\mathrm{MB}$ in the plating bath leads to the deposition of the $\mathrm{NiB}$ coating consisting of a smaller nodulus in size of approximately $80-260 \mathrm{~nm}$ and containing a lower $\mathrm{B}$ amount (Fig. 2c) as compared with that obtained from the plating bath containing a higher MB concentration (Fig. $4 \mathrm{a}-\mathrm{c}$ ). The sizes of nodules are significally larger and are in a range of approximately $130-320,225-600$ and 240-660 nm for the $\mathrm{NiB}$ coatings obtained from the plating bath containing a concentration of $\mathrm{MB}$ equal to $0.05,0.10$ and $0.20 \mathrm{~mol} \mathrm{~L}^{-1}$, respectively (Fig. $4 \mathrm{a}-$ c). As evident from the cross-section TEM im- age in Fig. 4d, the adhesion of the $\mathrm{NiB}$ coating to the substrate seems to be quite good.

The influence of the deposition rate and changes in the composition of the $\mathrm{NiB}$ coatings, depending on the concentration of a reducing agent (e.g. MB), are shown in Fig. 3, for a plating bath operated at $\mathrm{pH} 7$ and $30^{\circ} \mathrm{C}$ temperature. The results obtained have shown that the deposition rate of the $\mathrm{NiB}$ coatings remains practically unchanged with an increase in the concentration of MB from 0.02 to $0.10 \mathrm{~mol} \mathrm{~L}^{-1}$ (Fig. 3a). With a further increase in the $\mathrm{MB}$ concentration from 0.10 to $0.30 \mathrm{~mol} \mathrm{~L}^{-1}$, the deposition rate of the $\mathrm{NiB}$ coatings decreases significantly (Fig. 3a). The highest deposition rate of $1.02 \mathrm{mg} \mathrm{cm}^{-2} \mathrm{~h}^{-1}$ is obtained when the concentration of $\mathrm{MB}$ in the plating solution is in a range of $0.02-0.10 \mathrm{~mol} \mathrm{~L}^{-1}$. A general trend is observed when the $\mathrm{MB}$ concentration in the plating solution is elevated from 0.02 to $0.30 \mathrm{~mol} \mathrm{~L}^{-1}$ : the $\mathrm{Ni}$ content in the coatings decreases from 90 to 80 at.\% (Fig. $3 \mathrm{~b}$ ), while the amount of boron simultaneously increases from 10 to 20 at.\% (Fig. 3 c). 
SEM images of the $\mathrm{NiB}$ coatings deposited on $\mathrm{Cu}$ from the Ni-Gly plating baths, containing different concentrations of $\mathrm{MB}$, and operated at $\mathrm{pH} 7$ and $30^{\circ} \mathrm{C}$, are given in Fig. $4(\mathrm{a}-\mathrm{c})$. A cross-section TEM image of the $\mathrm{NiB}$ coating deposited on $\mathrm{Cu}$ at an $\mathrm{MB}$ concentration of $0.05 \mathrm{~mol} \mathrm{~L}^{-1}$ is shown in Fig. 4 d. The deposited NiB coatings have a cauliflower-like texture as shown in Fig. $4(\mathrm{a}-\mathrm{c})$. It can be noted that an increase in the $\mathrm{MB}$ concentration from 0.02 (Fig. 2c) to 0.20 (Fig. $4 \mathrm{a}-\mathrm{c}$ ) $\mathrm{mol} \mathrm{L}^{-1}$ in the plating solution caused a formation of more pronounced nodules in the coatings obtained. A lower concentration of $\mathrm{MB}$ in the plating bath leads to the deposition of $\mathrm{NiB}$ coatings consisting of smaller nodules with sizes of approximately 80-260 nm and a lower boron content (Fig. 2c) as compared with that obtained from the plating bath containing a higher concentration of $\mathrm{MB}$ (Fig. 4 a $-\mathrm{c}$ ). $\mathrm{NiB}$ coatings obtained from the plating bath containing $\mathrm{MB}$ concentrations of 0.05 , 0.10 and $0.20 \mathrm{~mol} \mathrm{~L}^{-1}$ exhibited significantly larger nodules with sizes ranging from approximately $130-320,225-600$ and $240-660 \mathrm{~nm}$, respectively (Fig. 4a-c). As evident from the cross-section TEM image in Fig. $4 \mathrm{~d}$, the $\mathrm{NiB}$ coating appears to be well adhered to the substrate.

The influence of the Gly concentration on the deposition rate of $\mathrm{NiB}$ coatings and their composition is shown in Fig. 5. When the concentration of Gly in the plating bath is increased from 0.10 to $0.40 \mathrm{~mol} \mathrm{~L}^{-1}$, the deposition rate decreases sharply (Fig. 5a). Theoretically, the ratio of the Ni and Gly in the complex must be 1:2. An additional amount of Gly ensures a sufficient stability of the plating solution. An increase in the Gly concentration in the solution from 0.10 to $0.20 \mathrm{~mol} \mathrm{~L}^{-1}$ leads to a decrease in the $\mathrm{Ni}$ content in the coatings obtained. In this case, the highest boron content was 11.8 at.\%, observed in coatings deposited when the Gly concentration in the plating bath was $0.20 \mathrm{~mol} \mathrm{~L}^{-1}$ (Fig. 5 c). Furthermore, with an increase in the Gly concentration up to $0.40 \mathrm{~mol} \mathrm{~L}^{-1}$, the $\mathrm{Ni}$ content in the coating increased slightly (Fig. 5b), while the B content decreased slightly (Fig. 5c).

The data on the dependence of the plating rate and the composition of the $\mathrm{NiB}$ coatings on temperature show that, in all cases, the Ni deposition rate increased with increasing the plating bath temperature (Fig. 6a). The highest coating depo-

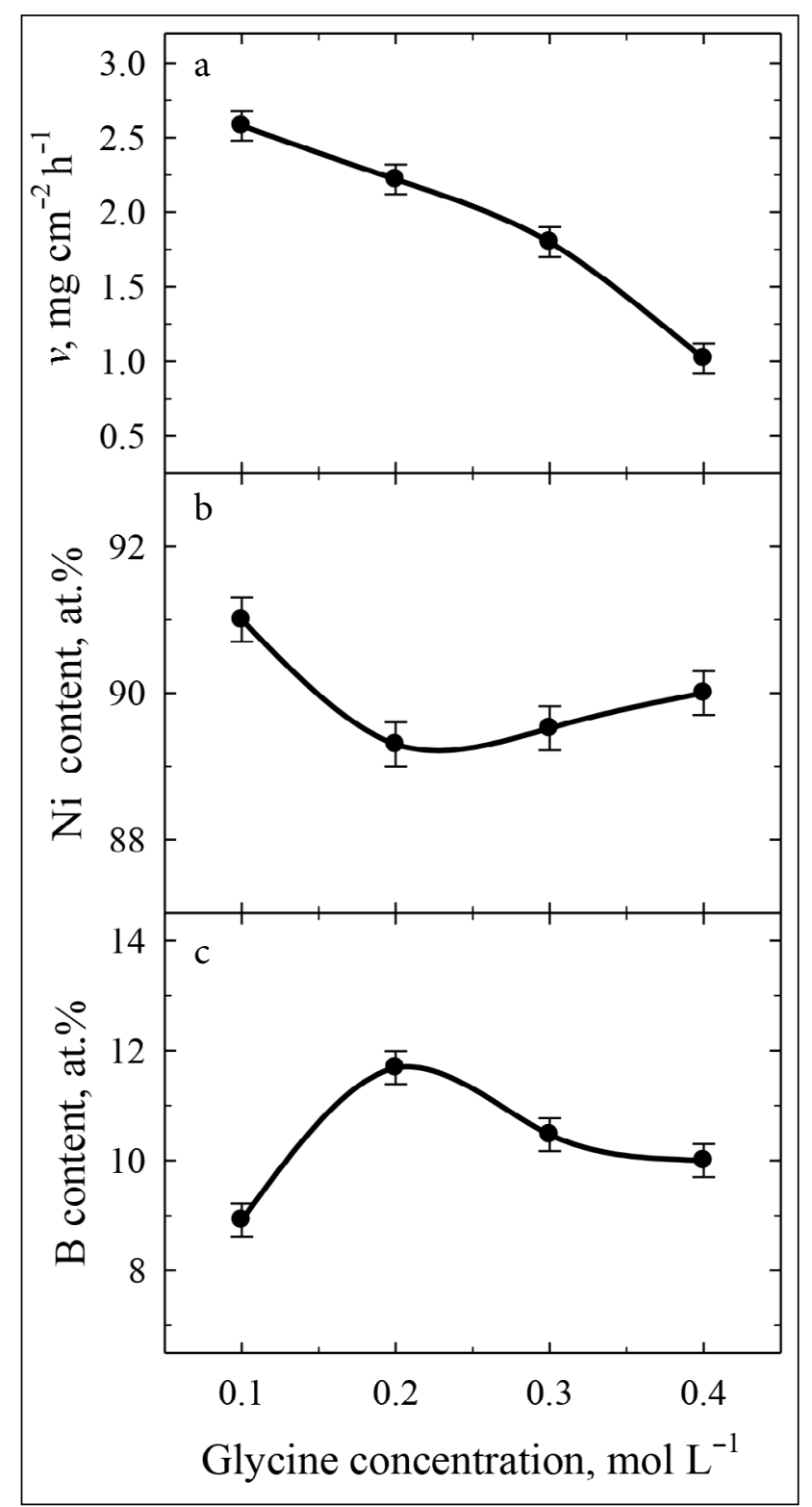

Fig. 5. Influence of the ligand (Gly) concentration on the deposition rate of the NiB coatings (a) and their composition (b, c). The solution composition ( $\mathrm{mol} \mathrm{L}^{-1}$ ): $\mathrm{NiSO}_{4}-0.05, \mathrm{MB}-0.02, \mathrm{CH}_{3} \mathrm{COONa}-0.04$, $\mathrm{pH} 7,30^{\circ} \mathrm{C}$

sition rate was obtained using the plating bath at $\mathrm{pH} 5$ and $60^{\circ} \mathrm{C}$ temperature (Fig. 6a). In this case, the deposition rate was $3.42 \mathrm{mg} \mathrm{cm}^{-2} \mathrm{~h}^{-1}$. Furthermore, an increase in temperature from $30^{\circ} \mathrm{C}$ to $60^{\circ} \mathrm{C}$ resulted in an increase in the deposition rate from 1.20 to $3.42 \mathrm{mg} \mathrm{cm}^{-2} \mathrm{~h}^{-1}$ at $\mathrm{pH} 5$, from 1.14 to $3.30 \mathrm{mg} \mathrm{cm}^{-2} \mathrm{~h}^{-1}$ at $\mathrm{pH} 6$, and from 1.02 to $3.00 \mathrm{mg} \mathrm{cm}^{-2} \mathrm{~h}^{-1}$ at $\mathrm{pH} 7$. At $\mathrm{pH} \mathrm{5}$, increasing the operating temperature of the plating bath led to an increase in the $\mathrm{Ni}$ content of the coating, whereas the B content decreased (Fig. 6b, c). ICPOES analysis of the $\mathrm{NiB}$ coatings produced shows 


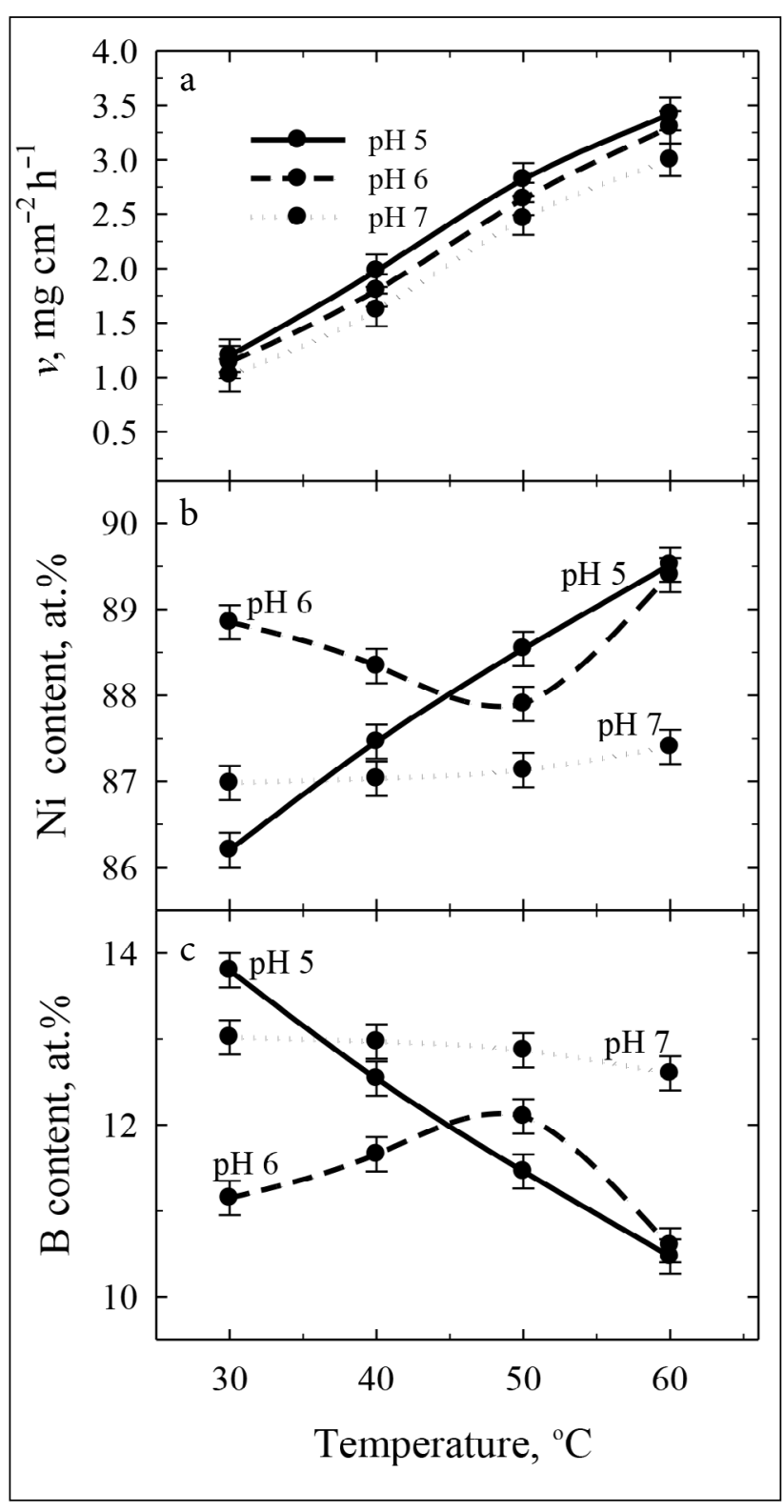

Fig. 6. Influence of temperature on the deposition rate of the NiB coatings (a) and their composition (b, c). The solution composition $\left(\mathrm{mol} \mathrm{L}^{-1}\right)$ : $\mathrm{NiSO}_{4}-0.05, \mathrm{MB}-0.05, \mathrm{CH}_{3} \mathrm{COONa}-0.04$, Gly -0.40

that the coatings contained $86.2-89.5$ at.\% of $\mathrm{Ni}$ and $10.4-13.8$ at.\% of boron. At $\mathrm{pH} 6$, an increase in the plating bath temperature from 30 to $50^{\circ} \mathrm{C}$ resulted in a diminished $\mathrm{Ni}$ content in the coatings obtained. Further increasing the temperature increased the $\mathrm{Ni}$ content, reaching 89.4 at.\%; however, the B content of these coatings decreased. When the plating bath was operated at $\mathrm{pH} 7$, the $\mathrm{Ni}$ and $\mathrm{B}$ contents in the coatings remained practically the same. In this case, the concentration of $\mathrm{Ni}$ detected in the coatings ranged from 86.9 to 87.4 at.\%, while that of boron ranged from 12.6 to 13 at.\% (Fig. $6 \mathrm{~b}, \mathrm{c}$ ). It should be noted that at higher temperatures, the deposi- tion of Ni occurred both in the solution bulk and on the walls of the vessel, indicating that the solutions were not adequately stable.

\section{CONCLUSIONS}

$\mathrm{NiB}$ coatings were deposited from a Ni-Gly plating solution onto $\mathrm{Cu}$, using $\mathrm{MB}$ as a reducing agent. The effects of the MB reducing agent, the Gly ligand, solution $\mathrm{pH}$ and temperature on the electroless deposition rate of the $\mathrm{NiB}$ coatings have been investigated.

It has been determined that $\mathrm{NiB}$ coatings, which exhibit a typical cauliflower-like texture, can be obtained in the Ni-Gly plating solution using $\mathrm{MB}$ as a reducing agent. Moreover, the electroless deposition rate and composition of the $\mathrm{NiB}$ coatings depend on the concentrations of the reducing agent (MB) and the ligand (Gly), as well as the $\mathrm{pH}$ and temperature of the plating solution. The highest deposition rate $\left(3.42 \mathrm{mg} \mathrm{cm}^{-2} \mathrm{~h}^{-1}\right)$ of the $\mathrm{NiB}$ coating was obtained when the plating bath was operated at $\mathrm{pH} 5$ and $60^{\circ} \mathrm{C}$ temperature. Using the electroless plating deposition method described, $\mathrm{NiB}$ coatings containing $10-20$ at.\% of boron can be obtained.

\section{ACKNOWLEDGEMENTS}

This research was funded by a Grant (M-ERA. NET-1/2016) from the Research Council of Lithuania. The author's research was performed in cooperation with the University of Tartu (Estonia), Latvian State Institute of Wood Chemistry (Latvia) and Horizon Pulp \& Paper Ltd (Estonia) under the M-ERA.NET 2 Project 'Woodbased Carbon Catalysts for Low-temperature Fuel Cells (WoBaCat)' (Reg. No. Project 3213). We would like to thank Editage (www.editage. com) for English language editing.

Received 21 November 2019 Accepted 5 December 2019

\section{References}

1. F. Bigdeli, S. R. Allahkaram, Mater. Des., 30, 4450 (2009).

2. M. Franco, W. Sha, G. Aldic, S. Malinov, H. Çimenoğlu, Tribol. Int., 97, 265 (2016).

3. A. S. Hamada, P. Sahu, D. A. Porter, Appl. Surf. Sci., 356, 1 (2015). 
4. C. K. Lee, Mater. Chem. Phys., 114, 125 (2009).

5. G. Straffelini, D. Colombo, A. Molinari, Wear, 236, 179 (1999).

6. W. Wang, W. Zhang, Y. Wang, N. Mitsuzak, Z. Chen, Appl. Surf. Sci., 367, 528 (2016).

7. H. Yang, Y. Gao, W. Qin, Y. Li, Surf. Coat. Technol., 281 (2015) 176-183.

8. M. Zhang, S. Mu, Q. Guan, W. Li, J. Du, Appl. Surf. Sci., 349, 108 (2015).

9. D. Dong, X. H. Chen, W. T. Xiao, G. B. Yang, P. Y. Zhang, Appl. Surf. Sci., 255, 7051 (2009).

10. A. Agarwal, M. Pujari, R. Uppaluri, A. Verma, Ultrason. Sonochem., 21, 1382 (2014).

11. Z. Sharifalhoseini, M. H. Entezari, R. Jalal, Surf. Coat. Technol., 266, 160 (2015).

12. Y. de Hazan, D. Zimmermann, M. Z'graggen, et al., Surf. Coat. Technol., 204, 3464 (2010).

13. Y. El. Kaissi, M. Allam, A. Koulou, M. Galai, M. E. Touhami, Int. J. Chem. Mol. Nucl. Mater. Metall. Eng., 11(2), 162 (2017).

14. A. Mukhopadhyay, T. K. Barman, P. Sahoo, Surf. Coat. Technol., 321, 464 (2017).

15. Y. Sverdlov, V. Bogush, Y. Shacham-Diamand, Microelectron. Eng., 83, 2243 (2006).

16. R. Tarozaitė, A. Sudavičius, Z. Sukackienè, E. Norkus, Trans. Inst. Met. Finish., 92, 146 (2014).

17. V. Vitry, A. Sens, F. Delaunois, Mater. Sci. Forum, 783-786, 1405 (2014).

18. V. Vitry, F. Delaunois, Appl. Surf. Sci., 359, 692 (2015).

19. M. Islam, M. R. Azhar, N. Fredj, et al., Surf. Coat. Technol., 261, 141 (2015).

20. B. Oraon, G. Majumdar, B. Ghosh, Mater. Des., 29, 1412 (2008).

21. K. H. Lee, D. Chang, S. C. Kwon, Electrochim. Acta, 50, 4538 (2005).

22. V. Vitry, F. Delaunois, C. Dumortier, Surf. Coat. Technol., 202, 3316 (2008).

23. M. Anik, E. Körpe, E. Şen, E. Korpe, E. Sen, Surf. Coat. Technol., 202, 1718 (2008).

24. V. Vitry, A. Sens, F. Delaunois, Mater. Sci. Forum, 783-786, 1405 (2014).

25. V. Vitry, L. Bonin, Electrochim. Acta, 243, 7 (2017).

26. M. Lekka, R. Offoiach, A. Lanzutti, et al., Surf. Coat. Technol., 344, 190 (2018).

27. Y. Wang, X. Chen, W. Ma, Y. Shang, Z. Lei, F. Xiang, Appl. Surf. Sci., 396, 333 (2017).

28. Z. Abdel Hamid, H. B. Hassan, A. M. Attyia, Surf. Coat. Technol., 205, 2348 (2010).
29. Y. Lu, Q. Liang, L. Xue, Surf. Coat. Technol., 206, 3639 (2012).

30. W. Wang, Sh. Ji, I. Lee, Appl. Surf. Sci., 283, 309 (2013).

31. V. Bogush, Y. Sverdlov, H. Einati, Y. ShachamDiamond, Proceedings of the Advanced Metallization Conference, MRS Publications, San Diego, USA (2005).

32. Y. Shacham-Diamond, Y. Sverdlov, V. Bogush, R. Ofek-Almong, J. Solid State Electrochem., 11, 929 (2007).

33. T. Ritzdorf, ECS Trans., 6(8), 1 (2007).

34. H. Nakano, T. Itabashi, H. Akahoshi, J. Electrochem. Soc., 152, C163 (2005).

35. Y. Sverdlov, V. Bogush, H. Einati, Y. ShachamDiamand, J. Electrochem. Soc., 152, C631 (2005).

36. J. Gambino, J. Wynne, J. Gill, et al., Microelectron. Eng., 83, 2059 (2006).

37. S. Y. Chang, C. C. Wan, Y. Y. Wang, et al., Thin Solid Films, 515, 1107 (2006).

38. Z. Sukackienè, A. Balčiūnaitè, L. TamašauskaitèTamašiūnaitè, A. Selskis, V. Jasulaitienė, E. Norkus, Chemija, 26(3), 141 (2015).

39. Z. Sukackienè, A. Balčiūnaitè, L. TamašauskaitèTamašiūnaitè, V. Pakštas, A. Selskis, E. Norkus, J. Electrochem. Soc., 162(9), H734 (2015).

40. A. Balčiūnaitè, Z. Sukackienè, L. TamašauskaitèTamašiūnaitè, Ž. Činčienè, A. Selskis, E. Norkus, Electrochim. Acta, 225, 255 (2017).

41. A. Balčiūnaitè, Z. Sukackienè, L. TamašauskaitèTamašiūnaitė, D. M. F. Santos, E. Norkus, Chemija, 28(1), 21 (2017).

42. V. Mathew, S. Garcia, US patent No. 6924232B2, 2005.

43. C. F. Lane, Project for the DOE Chemical Hydrogen Storage Center of Excellence, Northern Arizona University (2006).

44. V. Vitry, L. Bonin, Surf. Coat. Technol., 311, 164 (2017).

45. J. Sudagar, J. Lian, W. Sha, J. Alloys Compd., 571, 183 (2013).

46. R. A. Shakoor, R. Kahraman, W. Gao, Y. Wang, Int. J. Electrochem. Sci., 11, 2486 (2016).

47. I. Celik, M. Karakan, F. Bulbul, Proc. Inst. Mech. Eng. B J. Eng. Manuf. Tribol., 230, 57 (2016).

48. P. Sahoo, S. K. Das, Mater. Des., 32, 1760 (2011).

49. R. Tarozaitè, A. Luneckas, Trans. Lithuanian Acad. Sci., B4, 3 (1986). 
Zita Sukackienè, Kornelija Antanavičiūtè, Jūratè

Vaičiūnienè, Loreta Tamašauskaitė-Tamašiūnaitė,

Arnas Naujokaitis, Eugenijus Norkus

CHEMINIS NIKELIO-BORO DANGŲ

NUSODINIMAS NAUDOJANT REDUKTORIUMI

MORFOLINO BORANĄ

Santrauka

Nikelio-boro dangos buvo nusodintos cheminiu metalų nusodinimo metodu glicininiuose tirpaluose naudojant reduktoriumi morfolino boraną. Nustatyta, kad tokiu būdu galima gauti ịvairios sudèties, kokybiškas nikelio-boro dangas vario paviršiuje. Ištirta, kad $\mathrm{NiB}$ dangų nusèdimo greitis ir jų elementinè sudètis priklauso nuo reduktoriaus, ligando koncentracijos, nuo tirpalo pH ir temperatūros. Didžiausias dangų nusèdimo greitis nustatytas esant tirpalo temperatūrai $60{ }^{\circ} \mathrm{C}$ ir $\mathrm{pH} 5$, kai pasiekiamas didžiausias dangu nusėdimo greitis $-3,42 \mathrm{mg} \mathrm{cm}^{-2} \mathrm{~h}^{-1}$. Taikant chemini metalu nusodinimo metodą galima gauti $\mathrm{NiB}$ dangas, turinčias 10-20 at.\% boro. 